\title{
Migrations in Banat From World War II to 1996
}

Plavsa, J. E Bubalo-Zivkovic, Milka*

Abstract The region of Vojvodina and the region of Banat are under constant migrations of population. The reasons for migrations are numerous. The main reasons are peoples' quest for socio-economic welfare and changes in lifestyles. The most frequent reasons for changing permanent residence are of economic nature, although, simultaneously with the development of society migrations of religious, political and national nature become frequent. They occur as either forced or voluntary, mass or individual, planned or chaotic actions. All the reasons for migrations occurred in Banat throughout history. After the World War II, certain number of German population moved from Banat. They were replaced by about 81,000 postwar migrants. Between 1961 and 1991, migrations within Banat itself followed, especially migrations from rural areas into urban centers and regional centers. At the end of the $20^{\text {th }}$ century about 45,700 refugees from the republics of former Yugoslavia arrived in Banat.

Key words Banat, migrants, colonists, refugees
I has been very difficult to keep track of migrations in Banat through history. Historical sources and written data provide information on nations who used to inhabit the territory, but not about the size of their population. Being a crossroad for nomad nations and the stage of bloody wars, Vojvodina was successively under political government of conquering nations, who gained ruling position in the Middle Danube basin during various historical epochs. The region was conquered by: Goths, Visigoths, Sarmatians, Illyrians, Thracians, Dacians, Celts, Romans, Huns, Avars, Slovenes, and others.

Slovenes and Hungarians came to Vojvodina during the Avar Empire. With the arrival of Turks in $16^{\text {th }}$ century, great migrations occurred, which resulted in moving many nations from the area, mainly Serbs and Turks remained. Serbian majority remained after Turkish withdrawal.

In Austro-Hungarian Monarchy there was planned colonization, i.e. Teresa's and Josef's colonization, which brought large number of different ethnic groups into the region of Banat. The settlements first enlarged the number of Germans, and then large number of Hungarians arrived. Germans and Hungarians were settled as buffer zones between Serbs and Romanians. At that time small number of Slovaks, Czechs, Jews, Spaniards, Italians, and Frenchmen came and they either mixed with Germans and Hungarians or returned. However, precise data for the settlings are unavailable. Continuous statistics for this region were started in 1921, although the written data might not necessarily be true. Various restrictions and problems emerge in the study of migrations on the basis of available census data, because the data offer insufficient possibility for the research and comparison, especially the possibility of the research of the scope, direction, targets and distances of migrations, as well as the research of selective migrations. This paper analyzes migrations in the region of Banat from World War II (i.e. colonization of Banat, migrations between 1961 and 1991) to 1996 (i.e. refugees who settled in the region of Banat between 1990 and 1996).

\section{Planned settlement after the World War II}

Postwar planned migrations in Vojvodina were caused by emigration of Germans not by agrarian reform. After the emigration of Germans, significant extra land (about 668,000 hectares) was abandoned. The agrarian fund created in this way enabled the debt-free land to be distributed free of cost (Djurdjev, 1995)

Out of 16 municipalities in Banat, only Novi Knezevac and Kovacica were not included in the planned migrations. The area of Banat, observed in present administrative borders, got 80,783 inhabitants in planned migrations what is $15,6 \%$ of the population at that time. According to census in 1948 the population of Banat was 599,120. If there were no planned migration the number would decrease to 518,337. In this planned migrations Banat settled $37,3 \%$ of the total number of migrants in Vojvodina. From the total number of migrants, 1,318 were in-migrants (i.e. people who migrated from the territory of other municipality in Banat or from Backa or Srem), 79,465 were out-migrants or $98.4 \%$ of the total (i.e. people who migrated from other regions from SFR Yugoslavia). The largest number of migrants in Banat is from Bosnia and Herzegovina (58.4\%), and Serbia $(22.0 \%)$. The remaining $19.6 \%$ of migrants is from Macedonia (11.4\%), Croatia $(3.4 \%)$, Slovenia $(1.9 \%)$, Kosovo $(1 \%)$, Montenegro ( $0.9 \%)$, and other countries $(0.8 \%)$. Migration bonds with the territories of Croatia and Serbia were strong in the past too. Planned migration strengthened new migration currents, e.g. from Bosnia and Herzegovina, which continued its independent development later, as a contrast to the current from Montenegro which seized its development. Similar situation occurred with Slovenia and Macedonia. The main reasons for these are remote- 
ness and language barrier as well as a smaller number of potential settlers (Djurdjev, 1995).

Serbia without Provinces is divided into four demographic regions. Out of those regions, the largest number of settlers was from the Starovlaski region 17,513 (49.3\%), then from the Sumadija region $4,356(24,9 \%)$, from the South Morava region 3,204 (19.3\%), from the Eastern Serbia region 1,297 (only 7.4\%) and from the Kosovo region only 812 settlers.

Small number of migrants came from Croatia, only 2,727 i.e. $3.4 \%$ of the total number of migrants settled in Vojvodina. Territory of Croatia is divided into four regions. The largest number of settlers came from Dalmatia (54.5\%), then from Lika and North Adriatic (32.7\%), from Middle Croatia (10.3\%) and from Slavonia (only $2.5 \%$ of the total number of settlers from Croatia).

Slovenia, as a developed part of former Yugoslavia after the World War II, contributed with a rather small number of immigrants, only 1,538. The largest number of immigrants $(68.7 \%$ of the total number of migrants from Slovenia) was from Eastern Slovenia. There were only 481 migrants (31.3\%) from Western Slovenia.

Demographic region of Bosnia and Herzegovina contributed with the largest number of migrants in Banat area, about $60 \%$ or 46,445 people, who made $7.8 \%$ from the total population in Banat according to the census in 1948 . The region is divided into five demographic regions of the second level. From these regions, mass migrations were from the area of Bosanska Krajina 28,384 people $(61.1 \%$ of the total number of migrants from Bosnia and Herzegovina).

9,093 migrants or $11.4 \%$ of the total number of migrants who came to Banat was from Macedonia. Demographic region of Montenegro contributed with a small number of migrants, only 689 people, what made less than $1 \%$ of the total number of the migrants in Banat at that time. According to the census of migrants in 1948, there were immigrants from abroad. Mainly, they were returnees, who considered it safe to return to their native country. The largest number of them came from Albania (307 or $47.4 \%$ of the total number of migrants in Banat who came from abroad), and Romania (286 or $44.1 \%$ ) whereas from Greece, Italy, Hungary,

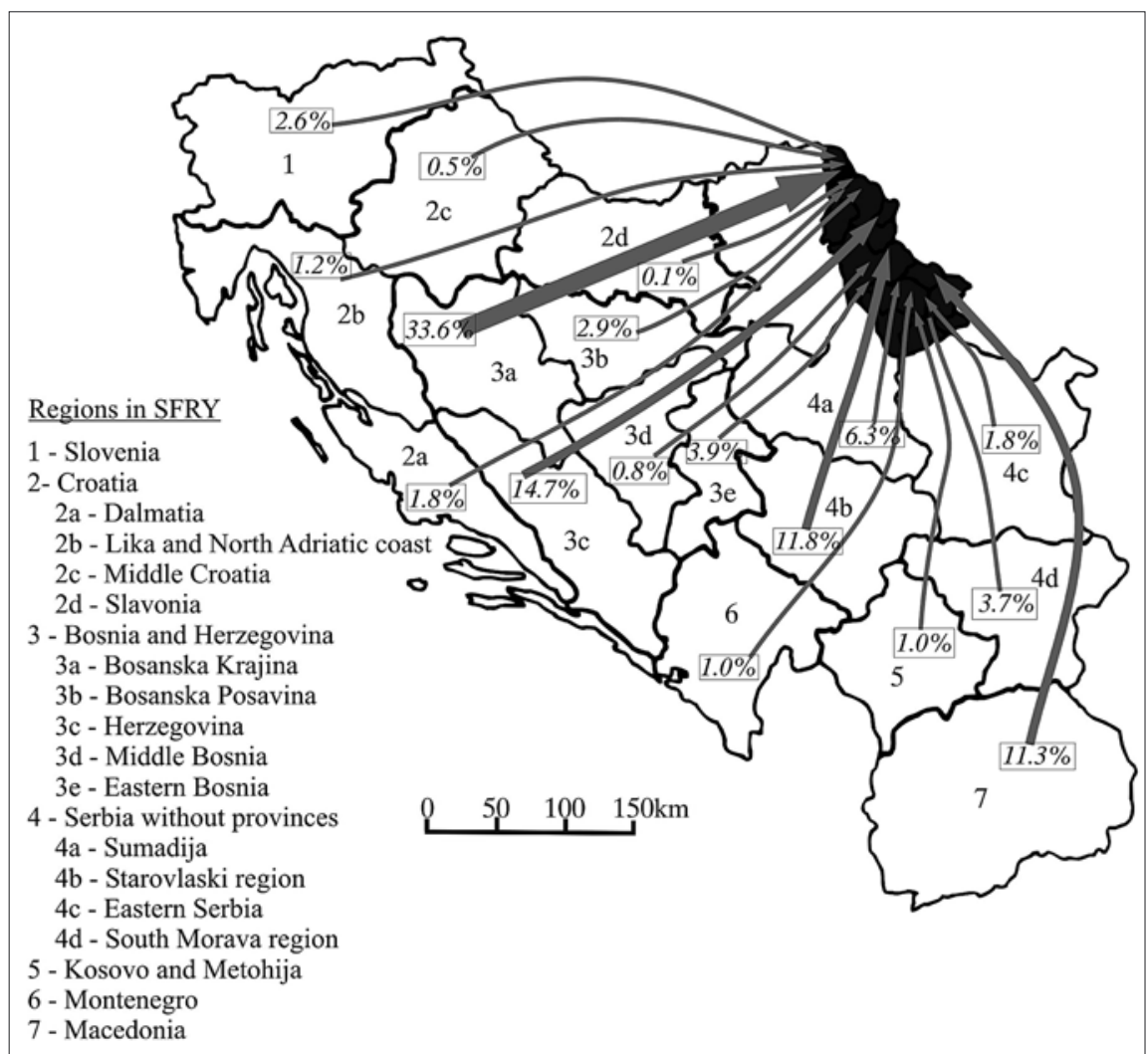

- Figure 1. Map of regions in SFRY from which planned settlement was performed

USSR and Czechoslovakia came significantly less migrants (the total number is less than 20).

\section{Migrations between 1961 and 1991}

After the WW II migrations in Yugoslavia intensified. The causing factors of intensified migrations were mainly found in changes of social relations and political system, economic development, and especially industrialization (Obradovic, 1955).

tion of population in rural settlements, which consequently decreased (group of authors, 1995).

Oscillations in the number of migrants are evident in Banat. In the period of intensified out-migrations, emigrations and migrations villagetown (1961-1971), the percentage of migrant population increased. In 1971 almost half of the population were migrants (table 1). Between 1971 and 1991 decrease in the number of migrants was recorded (for about 30,000 people),

Table 1 Migrant and native population in Banat

\begin{tabular}{|l|r|r|r|r|r|}
\hline \multirow{2}{*}{ Census } & \multirow{2}{*}{ Total population } & \multicolumn{2}{|c|}{ Autochthonous } & \multicolumn{2}{c|}{ Migrant } \\
\cline { 3 - 6 } & & Total & $\%$ & \multicolumn{1}{c|}{ Total } & \multicolumn{1}{c|}{$\%$} \\
\hline 1961 & 658,732 & 366,347 & 55.6 & 292,385 & 44.4 \\
\hline 1971 & 666,559 & 357,872 & 53.7 & 308,687 & 46.3 \\
\hline 1991 & 648,611 & 369,339 & 56.9 & 279,272 & 43.1 \\
\hline
\end{tabular}

Source: Census books 1961, 1971 and 1991

In-migrations in the post war period resulted in completely new distribution of population. In the period of accelerated socio-economic development the most frequent migrations were villagetown, migrations within urban settlements (from smaller and medium size towns to cities). Within municipalities, the direction of migrations was towards the centers or faster developing parts. Following this scheme, migrations resulted in higher concentration of population in small area (municipality, town and city centers), and lower concentra- which was the result of decrease of immigration. The increase on number of migrants occurred in the next decade as a consequence of all the events in the former Yugoslavia.

Migrants in Vojvodina in 1961 were mainly those who migrated from the republics of former federal state $(44.1 \%)$. The large number of migrants was the result of post war planned migrations, which were performed on the territory of Vojvodina, including Banat. The percentage of migrants from other republics in Banat was similar to the 
Table 2 Migrant population according to type of migrations between 1961 and 1991 in Banat

\begin{tabular}{|l|r|r|r|r|r|r|}
\hline \multirow{2}{*}{ Migrated from: } & \multicolumn{2}{|c|}{1961.} & \multicolumn{2}{c|}{1971.} & \multicolumn{2}{c|}{1991.} \\
\cline { 2 - 7 } & \multicolumn{1}{|c|}{ Number } & \multicolumn{1}{c|}{$\%$} & \multicolumn{1}{c|}{ Number } & \multicolumn{1}{c|}{$\%$} & \multicolumn{1}{c|}{ Number } & \multicolumn{1}{c|}{$\%$} \\
\hline Total & 292,385 & 100.0 & 308,687 & 100.0 & 279,272 & 100.0 \\
\hline Same municipality & 48,583 & 16.6 & 60,874 & 19.7 & 59,235 & 21.2 \\
\hline $\begin{array}{l}\text { Other municipality but } \\
\text { same republic }\end{array}$ & 108,556 & 37.1 & 168,580 & 54.6 & 92,356 & 33.1 \\
\hline Other republic & 124,687 & 42.6 & 64,677 & 21.0 & 118,273 & 42.3 \\
\hline Other country & 8,091 & 2.8 & - & - & - & - \\
\hline Unknown & 2,468 & 0.8 & 14,556 & 4.7 & 9,408 & 3.4 \\
\hline
\end{tabular}

Source: Census books 1961, 1971 and 1991

Table 3 Migrant population according to the type of place they came from between 1961 and 1991 in Banat

\begin{tabular}{|l|r|r|r|r|r|r|}
\hline \multirow{2}{*}{ Migrated from: } & \multicolumn{2}{|c|}{1961.} & \multicolumn{2}{c|}{1971.} & \multicolumn{2}{c|}{1991.} \\
\cline { 2 - 7 } & \multicolumn{1}{|c|}{ Number } & \multicolumn{1}{c|}{$\%$} & \multicolumn{1}{c|}{ Number } & \multicolumn{1}{c|}{$\%$} & \multicolumn{1}{c|}{ Number } & \multicolumn{1}{c|}{$\%$} \\
\hline Total & 292,385 & 100.0 & 308,687 & 100.0 & 279,272 & 100.0 \\
\hline Rural places & 222,474 & 76.1 & 217,456 & 70.4 & 103,894 & 37.2 \\
\hline Mixed type places & 10,907 & 3.7 & 18,518 & 6.0 & 73,881 & 26.5 \\
\hline Urban places & 48,019 & 16.4 & 58,226 & 18.9 & 92,089 & 33.0 \\
\hline Unknown & 10,985 & 3.8 & 14,487 & 4.7 & 9,408 & 3.3 \\
\hline
\end{tabular}

Source: Census books 1961, 1971 and 1991

percentage of migrants in the whole Vojvodina (42.6\% - table 2). There were fewer migrants who came from other municipalities of the same republic, or province. The number of those on the territory of Vojvodina reached $1 / 5$ $(38.8 \%)$, whereas in Banat the number was less (37.1\%). Rather high migratory level within the republics is the result of population migrations towards larger republic or province centers, which started in 1950s and intensified in 1960s and 1970s. In 1961 the percentage of local migrants was $14.1 \%$ for Vojvodina and $16.6 \%$ for Banat. This was the decade when intensified migrations within the same municipality started. Immigrants were the smallest part of population, because that was the period when people from Yugoslavia emigrated to western countries (Germany, France, and Switzerland) and overseas. The census in 1971 indicated the increase of the number of migrants from other municipalities but from the same republics or provinces. The number of local migrants increased too, but the intensity of migrations between republics decreased as a direct result of peaceful post war period and smaller scope of inter-republic migrations after the post war planned settlings. The census in 1991 indicated intensified inter-republic migrations, which were the consequence of national misunderstandings, which occurred as early as 1980s on the territory of Yugoslavia. The percentage of those migrants in Vojvodina was $43.7 \%$ and in Banat
$42.3 \%$. The number of migrants from other municipalities decreased to about $33 \%$ in Banat. Migrations from villages to towns were constantly intensified, and the number of migrants surpassed $1 / 5$ in Banat.

In analyzing migrations according to the type of place the migrants came

Table 4 Migrant population according to the period of migration in 1961

\begin{tabular}{|l|r|r|}
\hline & \multicolumn{1}{|c|}{ Banat } & \multicolumn{1}{|c|}{$\%$} \\
\hline Total & 292,385 & 100.0 \\
\hline Before 1940 & 63,696 & 21.8 \\
\hline $1941-1945$ & 32,537 & 11.1 \\
\hline $1946-1952$ & 75,060 & 25.7 \\
\hline $1953-1957$ & 56,810 & 19.4 \\
\hline $1958-1961$ & 60,768 & 20.8 \\
\hline Unknown & 3,514 & 1.2 \\
\hline
\end{tabular}

Source: Census books 1961

from, categorization of the places was one of the most difficult factors. Table 3 indicates that in 1961 the most of migrants were those from rural places (76.1\%) whereas far less migrants were from urban places (only 16.4\%). The rest of migrants came from the places of mixed type.

There was intensive migration (village-town) in Banat that resulted in $37.2 \%$ of those migrants in the total number of migrants in 1991. The census in 1991 indicated that the percentage of migrants who came from urban places was $33.0 \%$ and the rest of migrants were from mixed type places.

The following tables $(4,5$, and 6$)$ present intensity of migrations according to the periods and censuses. The analysis of the periods of migrations according to the census in 1961 has indicated that migrations were of the highest intensity in the post war period, what is logical because of the planned and organized settling in the north part of Serbia. The smallest number of migrants was during the World War II, and then there were some migrations after the post war planned settlings. However, there were planned migrations between the two wars and the number of the migrants from the pre war period was $1 / 5$.

In the census in 1971 the percentage of migrants from the post war period decreased. During planned migrations most of the people who migrated were middle aged or old, and deceased between 1961 and 1971, which was one of the causes of decrease in number of migrants in the observed period. According to this census, significant period in Banat was between 1953 and 1960 when $1 / 5$ of the total of migrants came. That was the time of migrations from underdeveloped to developed parts in former Yugoslavia in order to find better employment. Intensive migrations of the same type occurred up to 1965 . By the year 1971, fewer people migrated because that was the period of prosperity in former Yugoslavia, when equal development of most of the parts of the country was in progress.

Analysis of the census data in 1991 indicates that in the pre war and war period brought the least number of migrants (table 6). The largest number of those migrants, evidenced in censuses in 1961 and 1971, deceased by 1991 and

- Table 5 Migrant population according to the period of migration in 1971

\begin{tabular}{|l|r|r|}
\hline & \multicolumn{1}{|c|}{ Banat } & \multicolumn{1}{|c|}{$\%$} \\
\hline Total & 308.687 & 100.0 \\
\hline Before 1940 & 44,980 & 14.6 \\
\hline $1941-1945$ & 22,007 & 7.1 \\
\hline $1946-1952$ & 58,237 & 18.9 \\
\hline $1953-1960$ & 67,385 & 21.8 \\
\hline $1961-1965$ & 54,390 & 17.6 \\
\hline $1966-1969$ & 34,886 & 11.3 \\
\hline $1970-1971$ & 17,062 & 5.5 \\
\hline Unknown & 9,740 & 3.2 \\
\hline
\end{tabular}

Source: Census books 1971

therefore the percentage of those migrants lessened significantly. In both observed areas (Vojvodina and Banat), the percentage of post war migrants and migrants who came due to economic reasons (1960-1970) is the largest. The period of migrations of economic character followed (1971-1991), i.e. mi- 


\section{pzc + GEOGRAPHICA ANNONICA}

grations village-town, smaller townsregional or province centers.

In 1961 the number of migrants in Banat was $34.5 \%$ of the total number of migrants in Vojvodina and it had tendency to decrease. Thus, in the census in $197133.9 \%$ of migrants were in Banat and by the year 1991 the number reached $30.5 \%$ which points to the fact that Banat has become less interesting for migrants since planned migrations.

\section{Refugee arrival \\ between 1990 and 1996}

There was a mass exodus of refugees heading towards FR Yugoslavia at the end of $20^{\text {th }}$ century. This mass migration outnumbered the Great Migration of Serbs, which occurred three centuries ago. According to the census (1996), there were 45,720 refugees in Banat. However, the actual number is higher because there were refugees who where not registered, i.e. those who managed to exchange their real estate at the very beginning of the war, reside permanently and obtain ID and other documents in FR Yugoslavia. Therefore, they are considered as residents of Banat. By 1996 vast number of refugees succeeded to immigrate to foreign countries and settle there. For a certain number of refugees the territory of Banat was only a transit stop.

The wave of refugees on the territory of Banat increased its population for $7.1 \%$ compared to the census data in 1991. The largest growth was recorded in Kikinda (9.9\%), Zitiste (9.7\%), and Secanj $(9.0 \%)$. Significantly less population growth was recorded in municipalities of Kovacica (2.2\%), Bela Crkva (4.2\%), and Coka (4.2\%).

Dispersion of migrants after the WWII was of high influence on the dispersion of refugees between 1990 and 1996. All municipalities of Banat were hit by the wave of refugees. The refugees arrived in large number to municipalities where their families or friends reside. The number of refugees in municipalities of Novi Knezevac and Kovacica is significantly smaller because there were no colonists in those two. The refugees arrived to 153 settlements out of the total of 176 settlements in Banat. The census in 1996 indicated that there were no refugees in 9 settlements in municipality of Bela Crkva (Banatska Subotica, Grebenac, Dobricevo, Dupljaja, Kajtasovo, Kaludjerovo, Kruscica, Crvena Crkva, and
Table 6 Migrant population according to the period of migration in 1991

\begin{tabular}{|l|r|r|r|r|}
\hline & Vojvodina & \% & \multicolumn{1}{|c|}{ Banat } & \multicolumn{1}{|c|}{$\%$} \\
\hline Total & 914,929 & 100.0 & 279,272 & 100.0 \\
\hline Before 1940 & 38,671 & 4.2 & 14,126 & 5.1 \\
\hline $1941-1945$ & 40,944 & 4.5 & 12,566 & 4.5 \\
\hline $1946-1960$ & 242,629 & 26.5 & 81,356 & 29.1 \\
\hline $1961-1970$ & 192,303 & 21.0 & 58,050 & 20.8 \\
\hline $1971-1981$ & 180,092 & 19.7 & 51,904 & 18.6 \\
\hline $1981-1991$ & 176,785 & 19.3 & 51,440 & 18.4 \\
\hline Unknown & 43,505 & 4.8 & 9,830 & 3.5 \\
\hline
\end{tabular}

Source: Census books 1991

Cesko Selo), 5 settlements in municipality of Vrsac (Vojvodinci, Vrsacki Rit, Kustilj, Markovac, and Socica), 2 settlements in municipality of Kovin (Malo Bavaniste, and Sumarak), 2 settlements in municipality of Secanj (Busenje, and Surjan), and 2 settlements in municipality of Coka (Banatski Monostor, and Vrbica), and 3 settlements in municipality of Novi Knezevac (Rabe, Siget, and Filic).

Out of the total of 16 municipalities in Banat, in 5 the number of refugees is less than 1,000, in 5 the number is between 1,000 and 2,000, in 2 the number is between 2,000 and 3,000. There are 4,094 refugees in the municipality of Vrsac, and 7,086 refugees in the municipality of Kikinda. According to the census in 1996 the number of refugees is the largest in the other two municipalities Zrenjanin and Pancevo, and it is nearly half of the total number of refugees in Banat (Zrenjanin - 9,423, and Pancevo - 10,925).

23,472 refugees from Croatia, 19,700 refugees from Bosnia and Herzegovina, 250 refugees from Slovenia, and 194 refugees from Macedonia arrived to Banat. The largest number of refugees from Croatia arrived from Dalmatian municipalities of Knin (2,843), and Benkovac $(1,364)$. Significant number arrived from Glina $(1,257)$, Petrinja $(1,222)$ and Karlovac (1,096). Between 500 and 1,000 people arrived from Vrginmost, Sisak, Gracac, Pakrac, Korenica, Vojnic, Donji Lapac, Zadar, Ogulin, Obrovac, and Nova Gradiska. Between 200 and 500 people arrived from Osijek, Otocac, Slunj, Sibenik, Gospic, Rijeka, Daruvar, Sinj, Drnis, and Vukovar. The total number of refugees who arrived from the remaining 75 municipalities in Croatia is less than 200.

19,700 people arrived to Banat from Bosnia and Herzegovina by 1996 what is $43.1 \%$ of the total number of refugees. The largest number arrived from Sarajevo (2,661 or $13.5 \%)$. Significantly less number arrived from other municipalities. 1,000-2,000 people arrived from municipalities of Sanski Most $(1,453)$, and Dvor (1,028). 500-1,000 people arrived from municipalities of Bihac, Bosansko Grahovo, Mostar, Bosanski Petrovac, Drvar, Kostajnica, Zenica, Tuzla and Mrkonjic Grad and 200-500 people arrived from municipalities of Bugojno, Bosanska Krupa, Sipovo, Banja Luka, Zavidovici, Konjic, Jajce, Teslic, Doboj, and Glamoc. From the remaining 84 municipalities in Bosnia and Herzegovina only 200 people arrived.

Migrations of Macedonians to FR Yugoslavia, after the independent state (Former Yugoslav Republic of Macedonia) had been created, was not intensive and numerous. The total of only 194 people arrived, 137 from Prilep and 57 from 10 other municipalities.

After the Republic of Slovenia had proclaimed its independence, 250 people from Slovenia came to Banat. Out of the total of 30 municipalities, the largest number arrived from the municipality of Ljubljana (58), Sezana (32). 10-20 people altogether arrived from six other municipalities, whereas less than 10 arrived from the remaining municipalities.

The census has recorded the occurrence of migrants arriving from the territory of Serbia, and Vojvodina. The census officials consider claim for those to misunderstood the questions from the questionnaire. Having arrived to Yugoslavia, most of the refugees were in search for the best place to reside and therefore frequently moved. Thus the places cited were only stops on their search for permanent residence. The total of 321 people or $0.7 \%$ claimed that. 14 people from 7 different municipalities in Montenegro, 207 people from 39 municipalities of Serbia, 86 people from 15 municipalities in Vojvodina, and 14 people from 6 municipalities in Kosovo arrived to Banat. 
According to the census in 1996, $17.6 \%$ of the total number of refugees in Vojvodina $(7.1 \%$ of the total number of refugees in Yugoslavia) arrived to Banat.

Population migrations after the WW II differ to great extent from the migrations at the end of the 20th century. The former were of economic character, whereas the later were caused by political turbulence on the territory of former Yugoslavia. Therefore the total number of migration population is different. Despite the differences, there was a relation between colonists and refugees and places from which both groups arrived. In certain number of municipalities, but not in all, the bond between the two is observable and stronger between migrants from Bosnia and Herzegovina than between migrants from Croatia. The large linear correlation between the number of colonists and the number of refugees by municipalities is shown by the coefficient of correlation 0.9. The coefficient is very close to number 1 , which confirms the fact that municipalities with greater share of colonists in the total mainly have greater share of refugees in the total, too.

\section{Conclusion}

The main characteristic of the migrations in Banat in the post war period is change of migrants. Withdrawal of German population was successively followed by planned migrations, and workers migrations to foreign countries. The process of colonization brought migrants from Bosnia and Herzegovina to the north of Banat and from south Serbia and Macedonia to the south of Banat.

The reasons for post war migrations, especially from 1971 were of economic character. Migrants were heading towards larger town centers - regional or province for easier employment and better choice of jobs. In addition, the period was characterized by village-town migrations for economic reasons, which resulted in abandoning agrarian areas in Banat and weakening of agriculture in the area.

The last decade of the 20th century migration processes were of political,

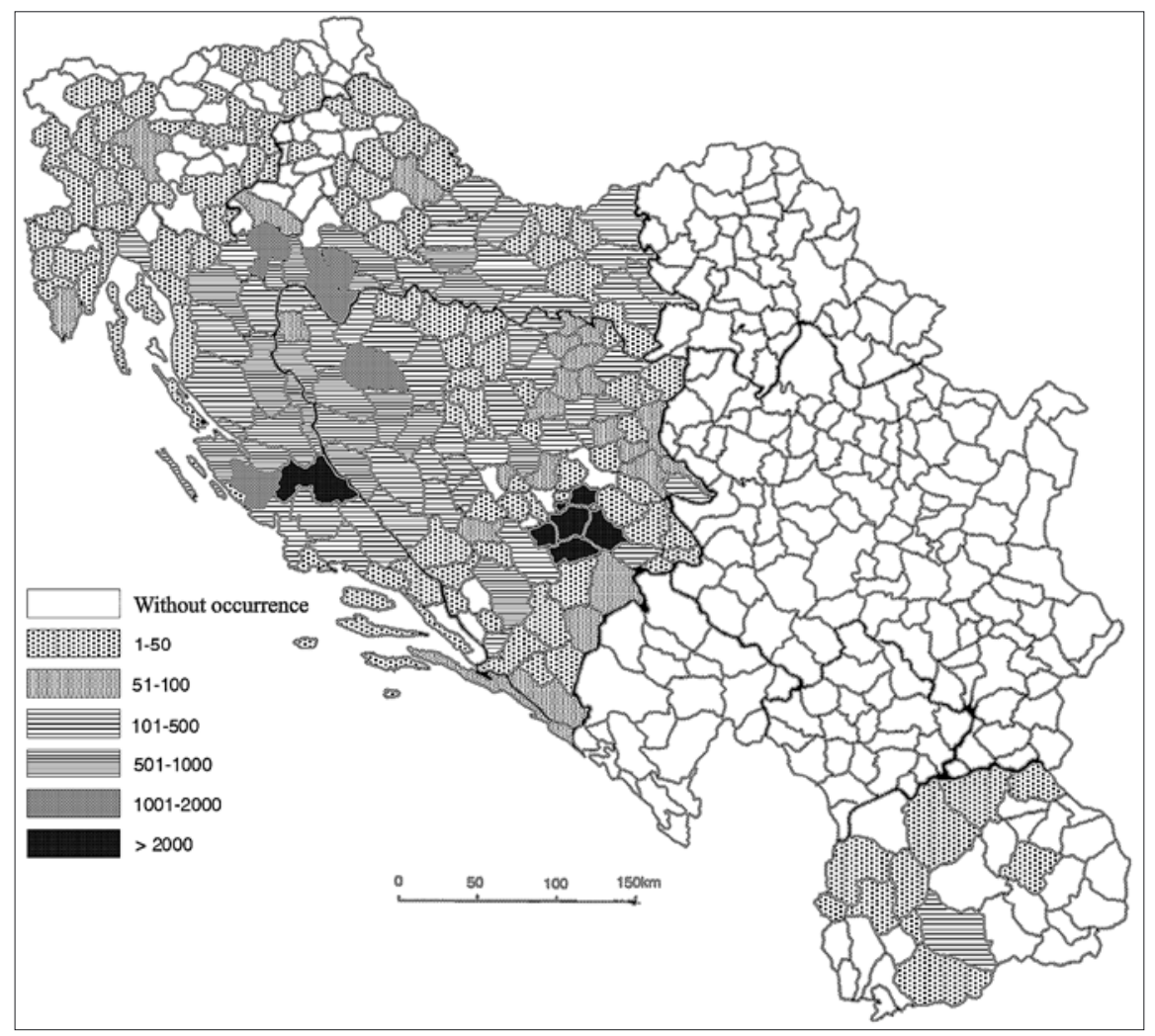

- Figure 2 Origin of refugees in Banat according to municipalities of the former SFRY

religious and ethnic character. The official data show 45.702 migrants. Dispersion of pre war and post war migrants as well economic development and employment possibilities were of high influence on the dispersion of refugees. The refugees enlarged the size of population in Banat and improved its age structure. However, it is usual that refugees adopt customs and habits of the autochthonous population and therefore the population of Banat will retain former balanced characteristics.

It is evident that Serbs participated in migration processes in 20th century more than other nationalities, which might be observed through migration analysis of the settlements where Serbs were minority.

Migrations retained its significant position in the demographic development of Banat for a long period. Premodern types of migrations that were gradually declining were refreshed with modern migration processes. Imposed migrations of political type were intensified in the previous 30-year period. Today we witness versatile migration processes according to their types, reasons and consequences. Either voluntary or imposed, migrations influenced more or less development of population in Banat, its size, territorial dispersion, and structure (age, education, ethnic, and etc.).

\section{References}

Gradski zavoda za statistiku, Popis izbeglica 1996, Beograd.

Grupa autora, (1995): Stanovnistvo i domacinstva SR Jugoslavije prema popisu 1991. Centar za demografska istrazivanja, Institut drustvenih nauka, Univerzitet u Beogradu, Beograd.

Djurdjev, B. (1995): Posleratno naseljavanje Vojvodine. Matica Srpska, Novi Sad.

Obradovic, S. (1995): "Uvod". U Konacni rezultati popisa od 15. marta 1948. Knjiga VI, Savezni zavod za statistiku, Beograd.

Savezni zavod za statistiku, Popis sta novnistva 1961, Migraciona obelezja, Rezultati po naseljima i opstinama, Beograd.

Savezni zavod za statistiku, Popis stanovništva 1971, Migraciona obeležja, Rezultati po naseljima i opštinama, 1973, Beograd.

Savezni zavod za statistiku, Popis stanovništva 1991, tabela 12, Beograd. 